\title{
東日本大震災時に地盤沈下を受けた沿岸域復旧 のためのジオシンセティックス適用の可能性
}

\author{
安原一哉 ${ }^{1} \cdot$ 薄井隆義 $^{2}$
}

\begin{abstract}
本文は，2011年3月11日東日本大震災で地盤沈降を起こした沿岸域の一地域を例に取り上げ，そこにおける 地盤沈下影響の実情と今後の対応策について考察した. 当該地域は, 地盤沈降によって, 約 $1 \mathrm{~m}$ 沈下を受けて いる. 現在は，応急復旧として，土のう敷設と矢板打設で応急的に浸水対策を講じている．この土のうとさら にやや高品質のジオシンセティックスを併用することによって, 応急的復旧よりは, やや耐久性のあり, 勒性 のある本復旧や強化復旧対策になりうる可能性を示唆した。 また, この地域に限ったことではないが，現在も すでに, 海面上昇の影響を受けていることから, 地盤と海面の長期的モニタリングの必要性とともに, 海面上 昇も考慮したジオテキスタイル利用による長期的適応策の必要性と可能性についても併せて強調した.
\end{abstract}

キーワード : 東日本大震災，地盤沈下，海面上昇，沿岸域，復旧・復興，ジオシンセティックス

\section{1. はじめに}

東日本大震災における地盤災害のうち，今までに経験 したことの少なかったものに，地款変動に伴う地盤沈降 があげられる。これが沿岸域では，地盤沈下を六し，高 潮や台風時に対して浸水などに対する脆弱性を増加させ ている. これに対する対策として, 粘り強い構造物の必 要性が期待されている.このような要請に応える方法の 一つとして, 従来のコンクリートやスティールなどの剛 な構造物から補強土のような柔な構造物の方が粘り強さ を賦与できることからこのような対応策に適していると 考えられる. 併せて, 補強土として用いられる土のうに
用いられる土や地盤沈下地帯のかさ上げ盛土に使われる 土に津波堆積土砂やがれき焼却灰を用いることができる なら，震災復旧や復興に貢献できると考えられるのでこ のことに関する可能性についても言及したい.

\section{2. 地盤沈降（沈下） と海面上昇}

\section{（1）東日本大震災後に生じたと思われる地盤沈下}

東日本大震災のような大きな地震では, 結果的に地盤 沈下につながる要因は多い. 表-1は現時点で考えられる 原因・誘因と復旧・復興対策についてまとめたものであ

表-1２011. 3. 11 東日本大震災で生じた地盤沈下の概要と対策例

\begin{tabular}{|c|c|c|c|c|c|c|}
\hline \multirow{2}{*}{ 地䑤沈下の程類 } & \multirow{2}{*}{ 原因 } & \multirow{2}{*}{ 锈因 } & \multirow{2}{*}{ 二次災害 } & \multicolumn{2}{|c|}{ 復旧対策 } & \multirow{2}{*}{ 檕興刘策 } \\
\hline & & & & 〈被兹した地域〉 & 後災告の色怡性のある地 & \\
\hline 沿岸域地盤沈下 & 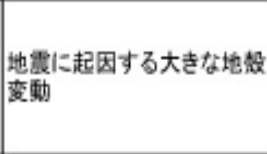 & 胞弱な地筧·地盤構成 & 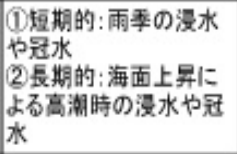 & 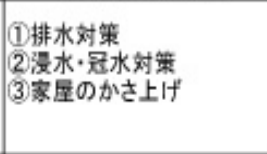 & & 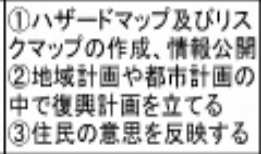 \\
\hline 盛土の沈下 & 盛土のせん断変形に伴う & 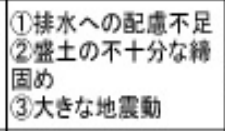 & $\begin{array}{l}\text { (1)雨系の土砂災害 } \\
\text { (1)余霞による土形災害 }\end{array}$ & 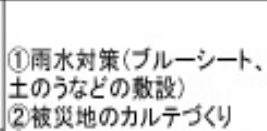 & 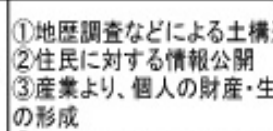 & $\begin{array}{l}\text { 造物や地盤の健康谸断 } \\
\text { E命を優先するという思想 }\end{array}$ \\
\hline \multirow{2}{*}{ 地震後の地盤沈下 } & 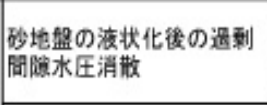 & 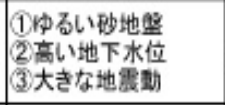 & 余震による再洨状化 & $\begin{array}{l}\text { (3)因々の事语に適した対 } \\
\text { 策の实跬 }\end{array}$ & 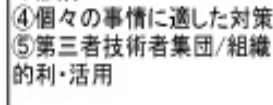 & 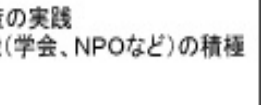 \\
\hline & 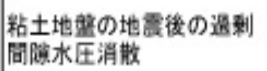 & $\begin{array}{l}\text { (1)軟翏な粘土地盤 } \\
\text { (2)大きな地震動 }\end{array}$ & 長期にわたる地盤沈下 & & & \\
\hline
\end{tabular}

\footnotetext{
${ }^{1}$ IGS 正会員, 茨城大学 名誉教授 地球変動適応科学研究機関（干310-8512 茨城県水戸市文京 2-1-1）

${ }^{2}$ JGS 正会員，パシフィックコンサルタンツ（株）東北支店（干980-0811仙台市青葉区一番町一丁目 9番 1 号）
} 


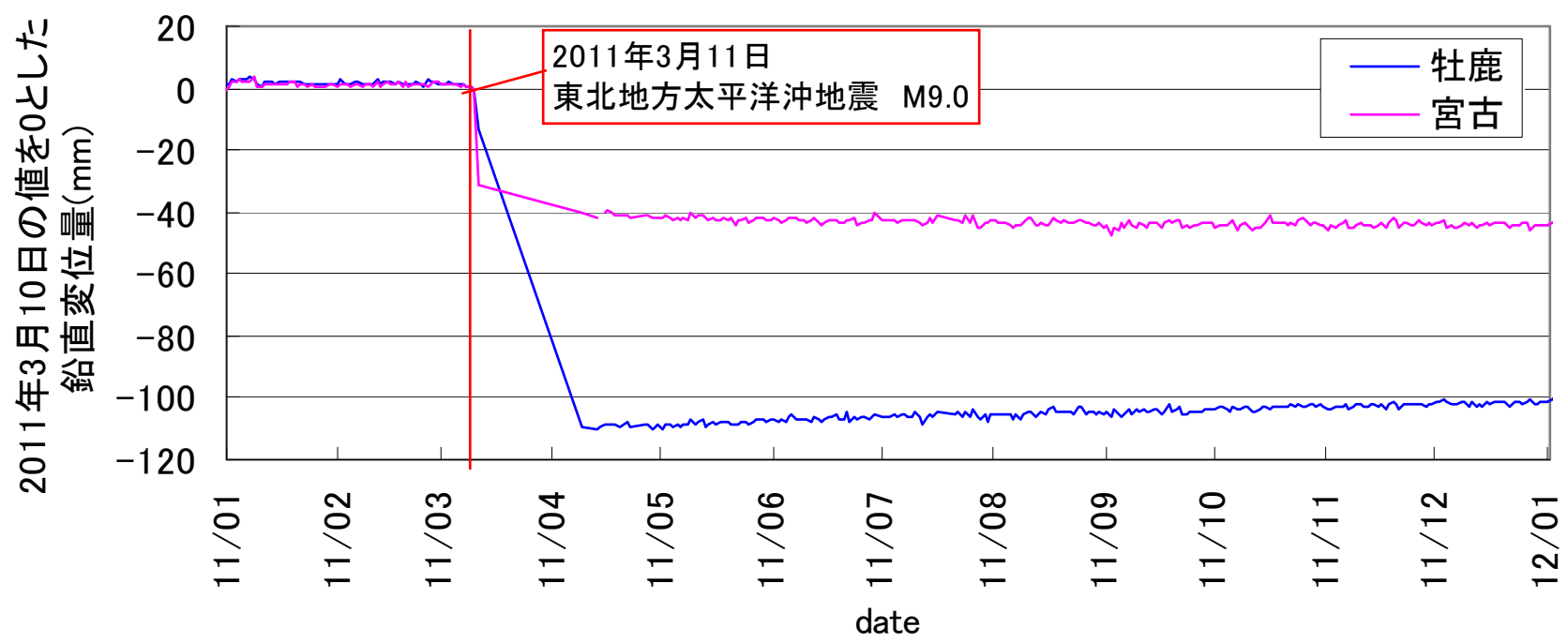

図一1 東日本大震災後の沿岸域地震地盤沈下の一例

る，東日本大震災で特徵的なのは，通常の地震ではほと んど見られなかった，地款変動による地盤沈降が生じた ことにある.もちろん，歴史的に振り返れば，同種の地 盤沈降が起きたことが記録に残っている事例 ${ }^{1}$ はある.

しかし，今回のように広い領域にわたって，大きな地盤 沈降を引き起こした例はまれである。このような地盤沈 降は，一方で，いったん起きてもまた膨張を引き起こし て時間とともに元に戻ることがあるとも言われているが， 他方, 地盤工学的にはそれを相殺する要因もある.

2011 年 3 月 11 日に発生した東北地方太平洋沖地震 (M9.0) 後の地盤変動として, 宮城県牡鹿郡女川町と岩手 県宮古市に存在する電子基準点の鉛直方向の経時変化を 図-1 に示している. 図-1 では，地震発生直前である 2011 年 3 月 10 日の観測データを基準として, 変位量を 整理した.この結果に基づいて地震後に発生した変位量 を整理した結果が図-1である.

これらのデータから，両地点ともに，地震直後には大 きな地盤変状が発生しており，その後は牡鹿では隆起傾 向，宮古では沈下傾向を示していることが分かる.

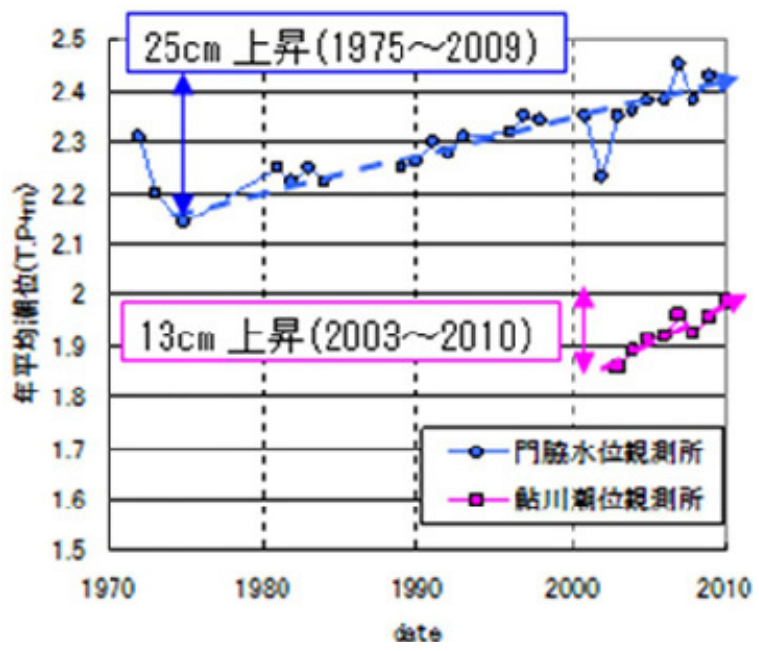

図-2 石巻市近傍における年平均潮位の経時的変化 ${ }^{2)}$

\section{(2)海面変位の傾向}

従来から言われているように海面が上昇すると高潮 時の浸水に対する危険性は増加すると考えられる. 図-2 は，石巻近傍の2地点における，潮位の経年的な変動を 示したものである．両者では傾向は異なっているが，総 じて年間 1 ～ $2 \mathrm{c} \mathrm{m}$ 程度の海面上昇が生じている.このこ とを踏まえて，地盤沈下地帯で海面上昇に見まわれたら どうなるか? をイメージしたものが図-3である，両者が 複合すると地盤沈下地帯は浸水に対してより脆弱になる.

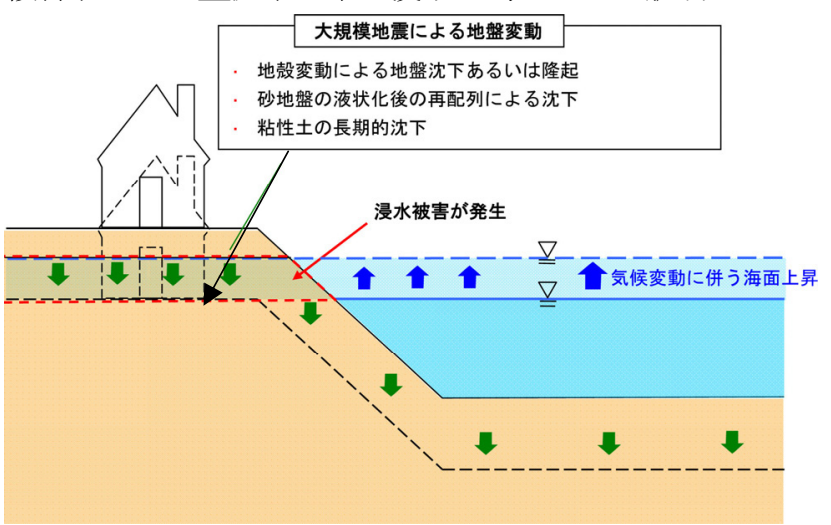

図-3 地盤沈下と海面上昇の複合化

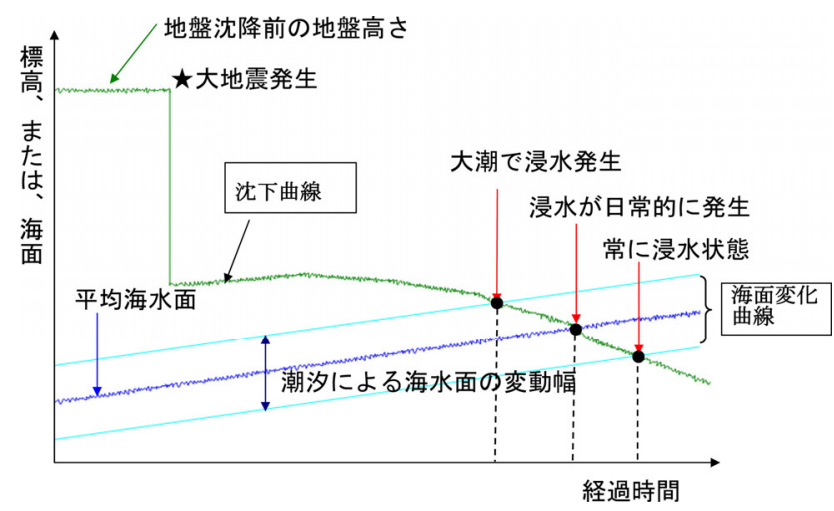

図-4 地表面変動と海面変位の経時変化の関係 


\section{（3）モニタリングの必要性}

図-4は，以上の考察を踏まえて，地盤高さと海面変位 の経時的な変化を重ね合わせて示したものである.この ような予測図が地域ごとに細かく準備されていれば，ど の時点でどのような適応策を講じていく必要があるかに ついておおよその予測をすることが出来る，その意味で は，適切な適応策を講じていくためには，地表面変位と 海面変位のモニタリングが不可欠である.

\section{3. 復旧・復興の考え方とジオシンセティックス 適用の可能性}

\section{（1）震災後の浸水事例}

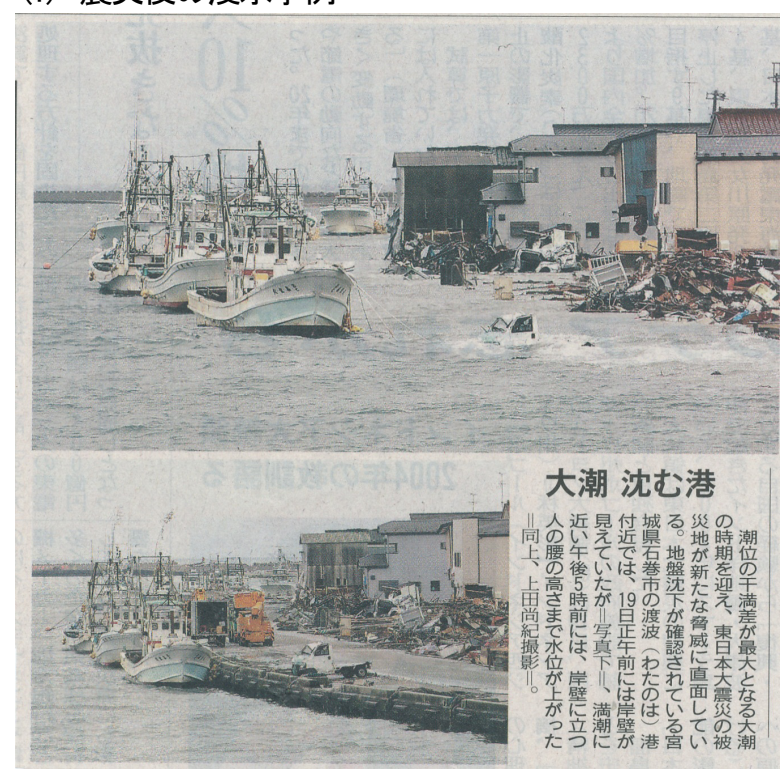

図-5 地盤沈降を受けた石巻港における満潮時における浸水の 様子 (読売新聞による $\left.{ }^{3)}\right)$

図一5は大地震後地盤沈降を受けた典型的な地域として 石巻市渡波地区の干潮時から満潮時の様子を示したもの である. 荒天時でない平時においても，満潮時には厳し い浸水の影響がみられることがわかる.

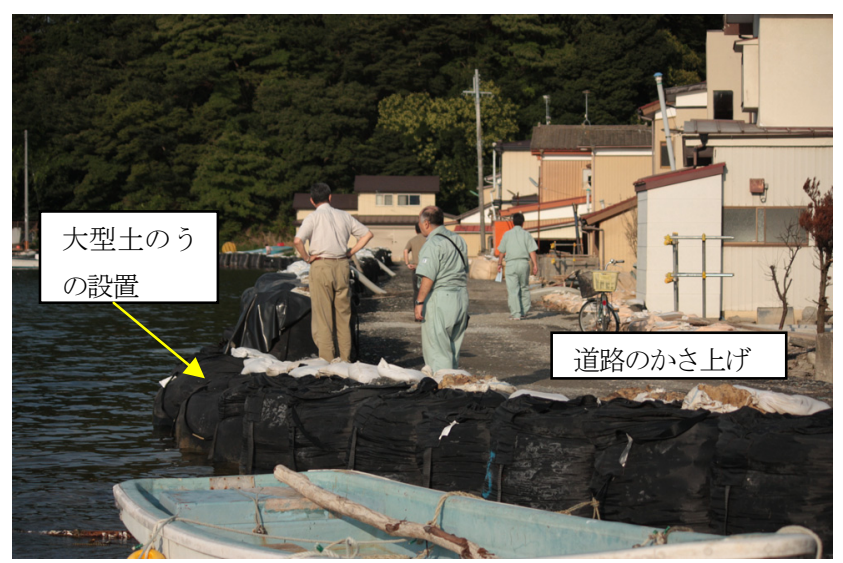

図-6 地盤沈降地帯における復旧対策の一例（石巻市渡波地 区）（2011年8月撮影）

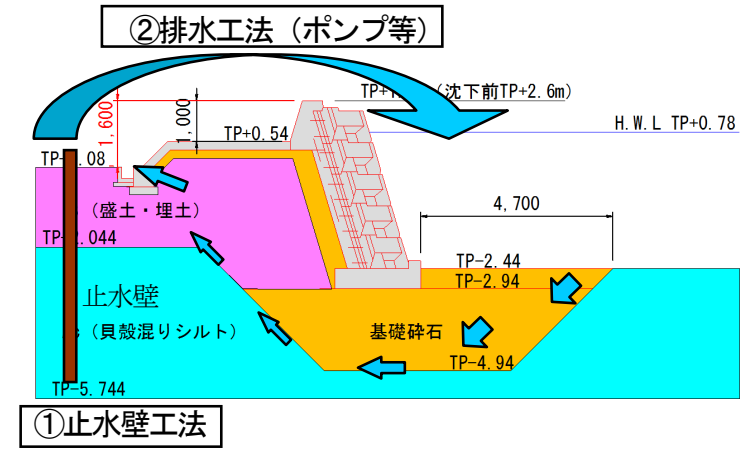

図-7 地盤沈降地帯における復旧対策の一例（石巻市折笠地 区）（宮城県 ${ }^{4}$ の資料による）

このような地域では, 震災後復旧対策が進められて いる. 典型的な方法は沿岸域における大型土のうの設置 である. 図-5は石巻市の渡波地区の震災直後に施工され た状況を示している.この大型土のうはあくまでも応急 復旧として施工されたもので而久性の点からは問題が残 る. (財) 土木技術センターでは，このことを改善するた めに而候性土のうの施工を推進し，設計・施工マニュア ルを発行している5。 これをさらに改善して本復旧や強 化復旧あるいは恒久復旧になりうるよう改善寸る余地が ある。

地盤沈下地域におけるもう一つの復旧対策は，図-5に も示したように，地盤沈下した部分のかさ上げである. この場合の問題は，道路など上物の無い平地においては かさ上げできても家屋のかさ上げが困難な点である.こ こでは別途新しい技術が必要である.

\section{（2）海面上昇の可能性と適応策}

地盤沈下地域においては，長期的には沈下の傾向が どのようになるのかということに加えて，もし気候変動 に伴う海面上昇が顕著に生じると寸ると，このことに対 する対応も含めて対策を立ておく必要がある。

\section{（3）ジオシンセティックスを利用した復旧対策} a）応急復旧への利用

石巻市渡波地区を念頭に置いて護岸壁崩壊の様子を

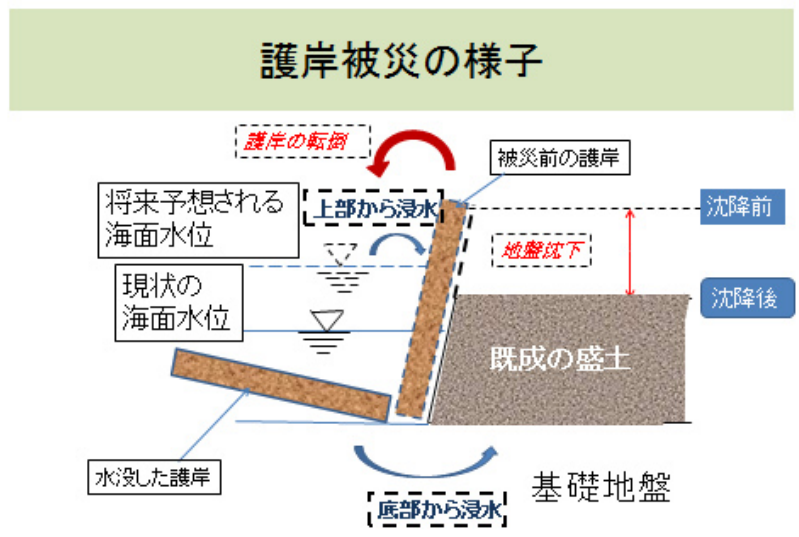

図-8＼cjkstart被災護岸の様子 


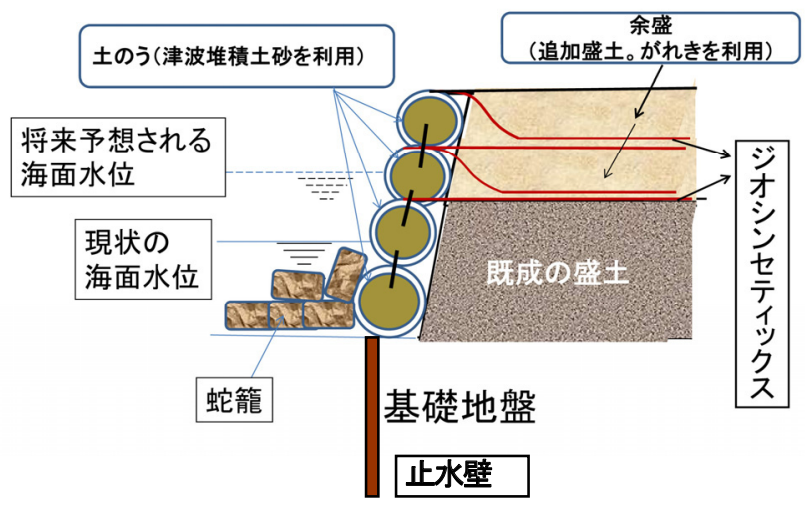

図-9 ジオシンセティックスによる復旧の一例

スケッチしてみると図-8のようになる，崩壊した護岸は 現在は図のように今も水没したままである。これを補う ために，震災直後に図-6に示したように，大型土のうで 対応している. この考え方を利用して，図-9に示したよ うに, 強度と岡性の高い複合不織布のようなジオシンセ ティックスを併用することによってやや耐久力があり耐 用性の長い補強土壁が構築できる。この場合に，土のう 同士を縫合やこう結などの方法で結合出来れば土のうの 機能が一層効果的に発揮されると考えられる.このこと は併せて，これらの土のうを保護するために土のう護岸 の前に蛇籠を設置できれば耐久性も増すと考えられる。 想定している渡波地区は内湾なので地震時には大きな津 波に見舞われることはなかったが，高潮の危険性がある ことからこのような対応も必要であろう.

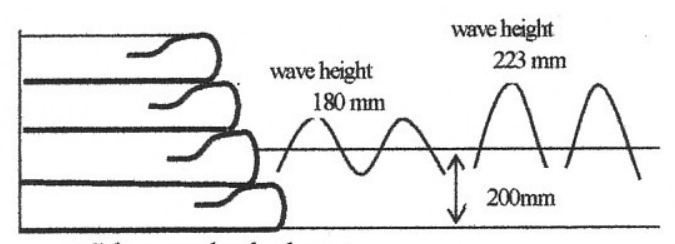

a.1) loose sand embankment

a.2) dense sand embankment

Case a) embankment reinforced with a nonwoven geotextile

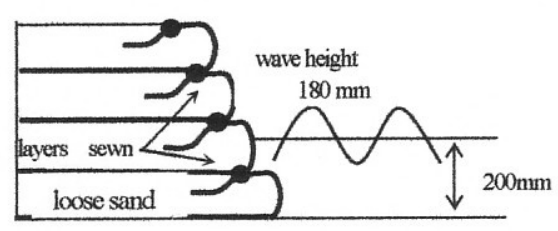

Case b) embankment reinforced with a nonwoven geotextile and its layers sewn together $100 \mathrm{~mm}$

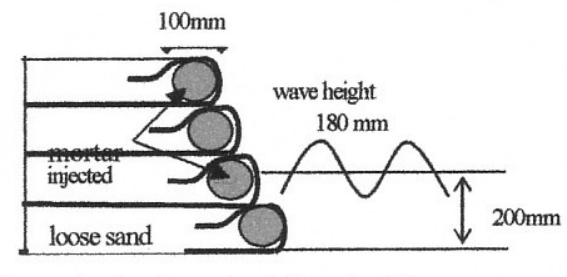

Case c)embankment reinforced with a nonwoven geotextile and

Case c) bankment reinforced with a nonwoven geotextile and the frontal part injected with mortar (cement-water 1:1)
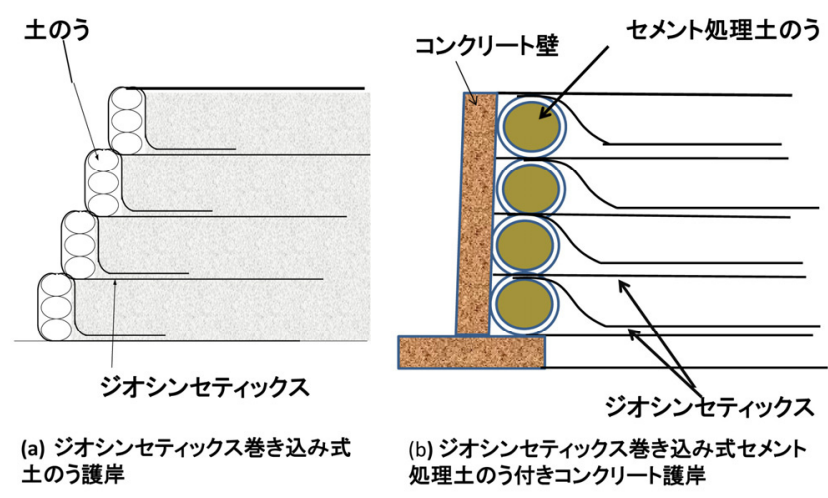

(a) ジオシンセティックス巻き込み式 土のう護岸 処理土のう付きコンクリート護岸

図-10 土のう式ジオシンセティックス補強土とコンクリート 併用護岸の併用

渡波地区では，潮位が高くなった時に下部からの浸水 に悩まされている，そのためには，ジオシンセティック スで巻き込まれた土のうを敷設する前に，図一にに示した ように，止水壁を敷設することが必要と思われる.

b）本復旧、強化復旧のあるいは恒久復旧方法

少し長期間にも耐えられる補強土とするために，先に 示したジオシンセティックス同士のこう結や縫合に加え て, 図-10 に示したように，土のうをセメント固化処理 することやコンクリート壁と組み合わせるなどの方法が 考えられる.

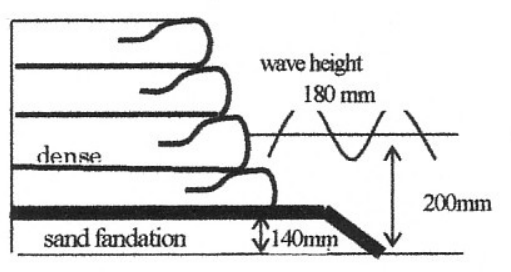

Case d) embankment reinforced with a nonwoven geotextile with sand foundation

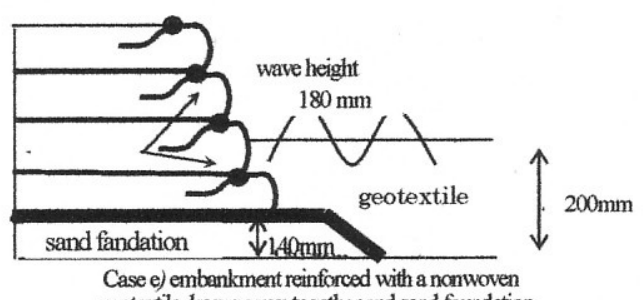
geotextile, layers sewn together and sand foundation $100 \mathrm{~mm}$

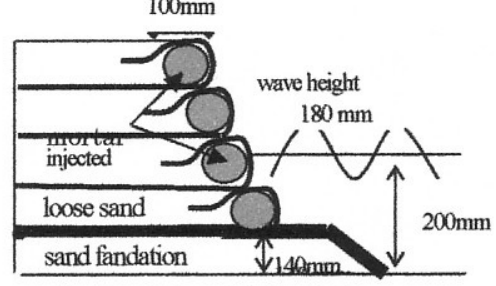

Case f) embenkment reinforced with a nonwoven geotextile, frontal part injected with mortar and with sand foundation 


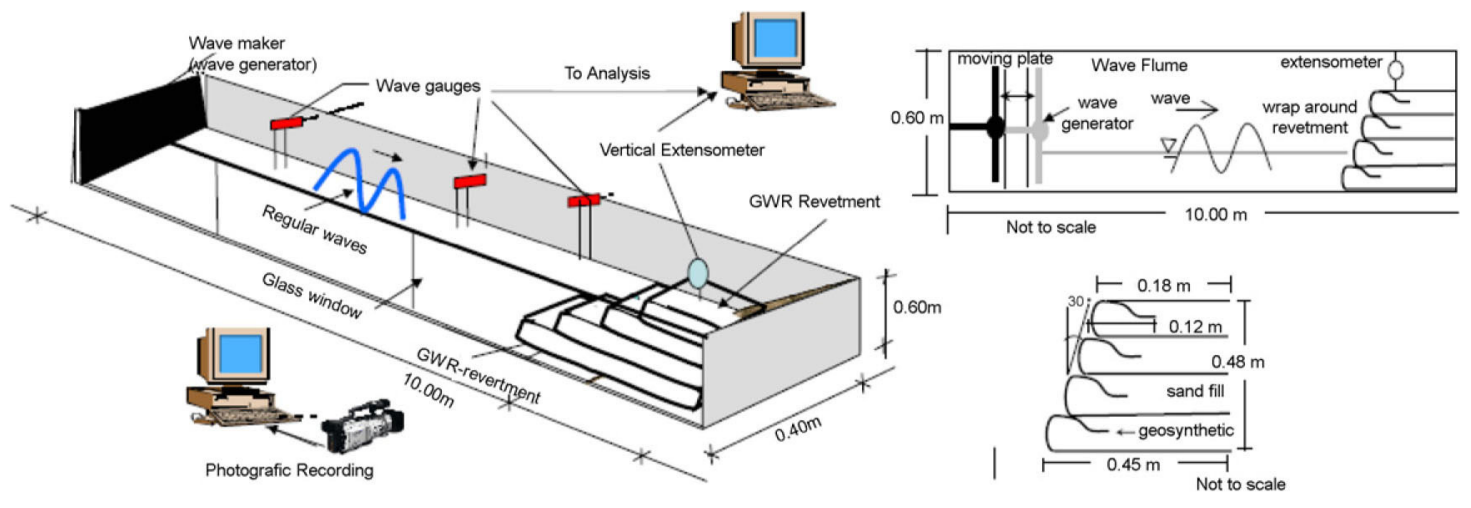

図-12 二次元水槽による模型実験の概要 (波高は、18 c mと 23 c m) ${ }^{77,8), 99,11), ~ 12) ~}$

\section{4. ジオシンセティックス適用復旧護岸の安定性 検証のための室内模型実験8, , 9, 10), 11)}

\section{（1）実験の概要}

ジオシンセティックス適用復旧護岸の安定性を確認 するために一連の室内模型実験を実施した．実験のシナ リオは，図-11に示す通りで，(a)巻き込み式補強に使う ジオシンセティックスの材料の違いの影響, (b) ジオシ ンセティックス同士の縫合の効果，(c)セメント固化処 理の効果を確認するための実験シリーズとした．模型実 験は，図-12に示すような二次元造波平面水槽に，補強 土護岸壁（高さ480mm，上端 $180 \mathrm{~mm}$ ，下端 $450 \mathrm{~mm}$ ）をセッ トした，補強盛土に使ったジオシンセティックスは，図 -13に示すような引つ張り特性を有する不織布（Nonwoven fabric）と複合不織布（ジオコンポジット， Composite fabric）を用いた. 盛土に用いられた砂は密 度 (i) $\rho_{\mathrm{d}}=1.42 \mathrm{~g} / \mathrm{cm}^{3}$ （ゆるい），（ii） $r_{d}=1.54 \mathrm{~g} / \mathrm{cm}^{3}$ （密 な）の豊浦標準砂 $\left(\rho_{\mathrm{s}}=2.64 \mathrm{~g} / \mathrm{cm}^{3}, \quad \phi^{\prime}=35^{\circ}, 40^{\circ}\right)$ である. 測定項目は，波浪の作用に伴う（i）天端の沈下 量, （ii）盛土の形状, 及び, （iii）試験後の盛土砂の密 度である．補強盛土に作用させる波浪の高さ $(180 \mathrm{~mm}$, $230 \mathrm{~mm})$ と周期 $(1.5 \mathrm{sec})$ は相似則を考慮して決められた.

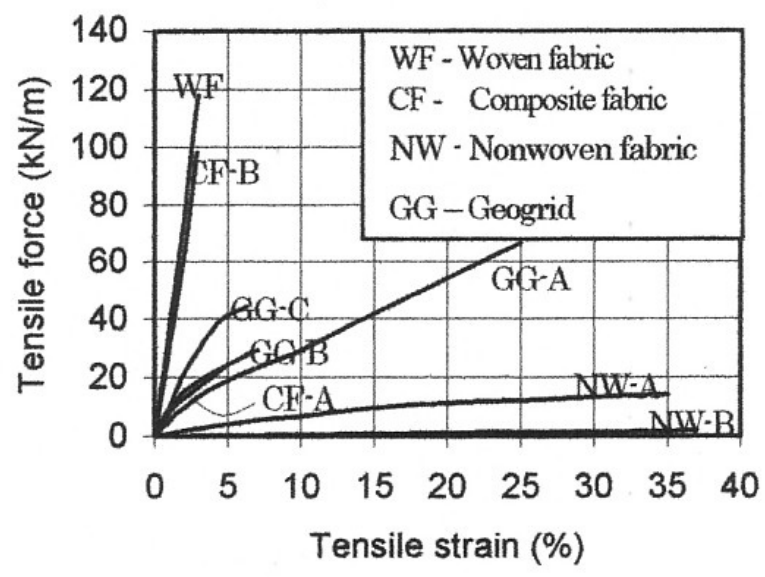

図-13 用いたジオシンセティックスの力学性状
(2) 模型実験結果と考察

a）ジオシンセシックスの種類（不織布と複合不織布） の影響

図-14 は天端の沈下量と経過時間の関係に及ぼすジオ シンセシックスの種類（不織布と複合不織布）の影響を 示したものである．図には砂の密度と波高の影響に関す る実験結果も含まれている.
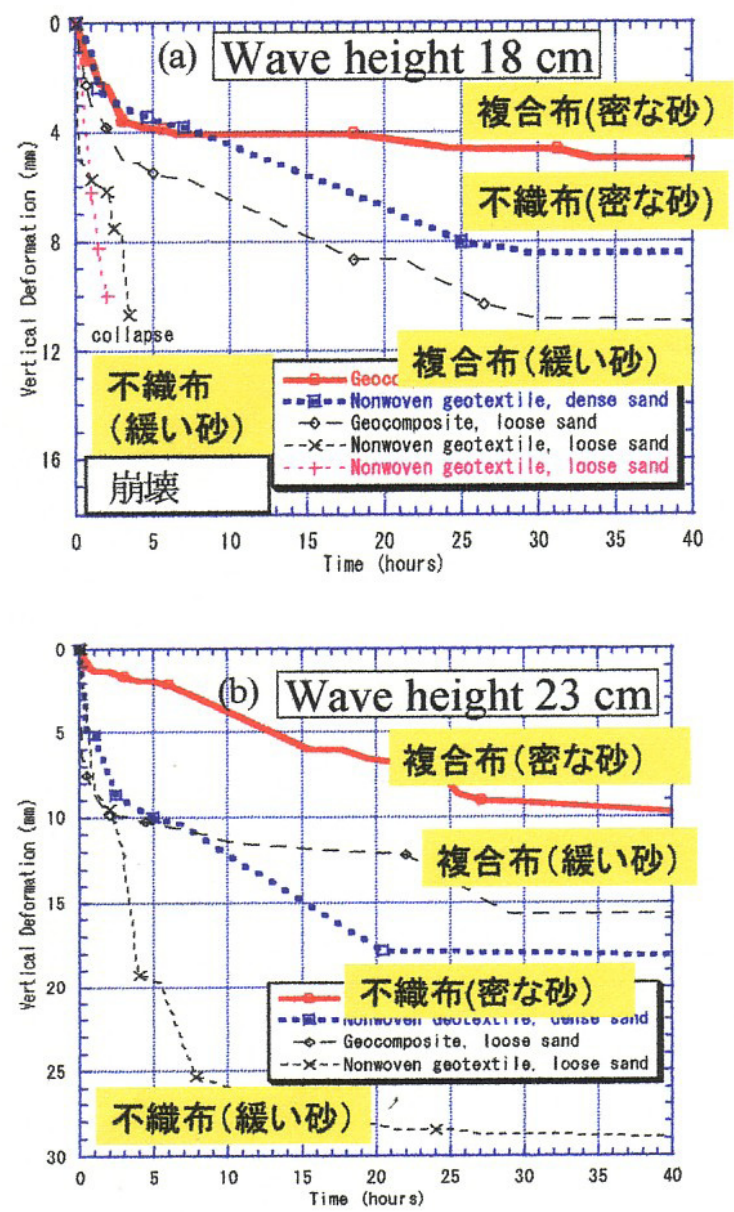

図-14 補強護岸の安定性に及ぼす波高とジオシンセティック スの種類の影響 
これによって以下のことが明らかになった.

(1)ゆるい砂の盛土を不織布で補強した場合は，盛土は崩 壊した．破壊は，特に引き波が作用するときで，盛土の 天端部が前倒しになるような崩壊の様式に，通常の斜面 の円弧すべりとは全く異なる形態を示した。このような 崩壊から，ジオシンセティックスの抵抗力は砂とジオシ ンセティイクスとの間の摩擦力と, ジオシンセティック ス巻き込み部におけるジオシンセティッックス相互の摩 擦力によるものということが分かった。これに対し，密 な砂の場合は，不織布でも複合不織布でも盛土は破壊す ることはなかった。 したがって，ゆるい砂の場合の崩壊 は波浪の繰返し作用によるゆるい砂の液状化に起因寸る ものと考えられる.

(2)一方，複合不織布による補強盛土補強は，盛土の変形 や破壊に対して安定性を維持できる.

\section{b) 補強効果}

ジオシンセティックス（特に，不織布）の補強効果 を挙げるために，（i）ジオシンセティックスを縫合 （ゼムクリップによる簡易な縫合）する，（ii）盛土フ ェーシング部分にモルタル（水・セメント比，1:1）を

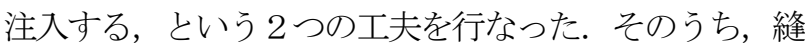
合の効果を上端部沈下一時間関係で比較した結果が図一 15である。これを見ると，複合不織布は，縫合しなくて

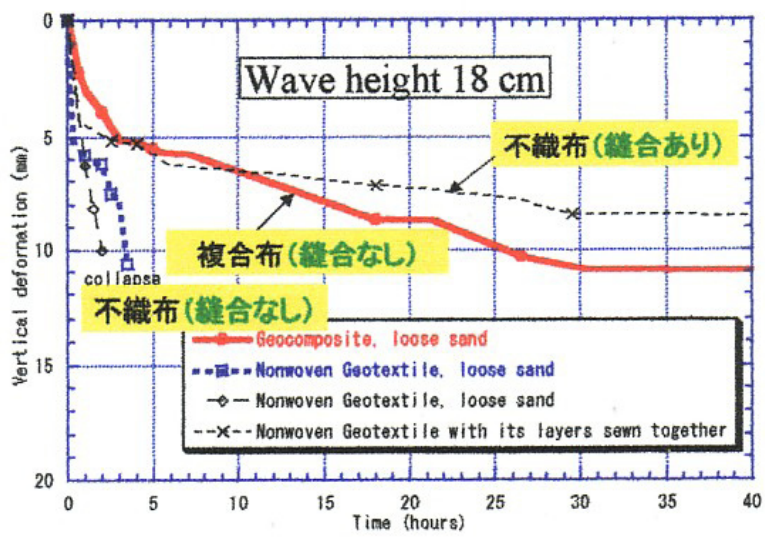

図-15 波浪作用による補強土壁の鉛直変位に及ぼすジオシン セティックス縫合の影響

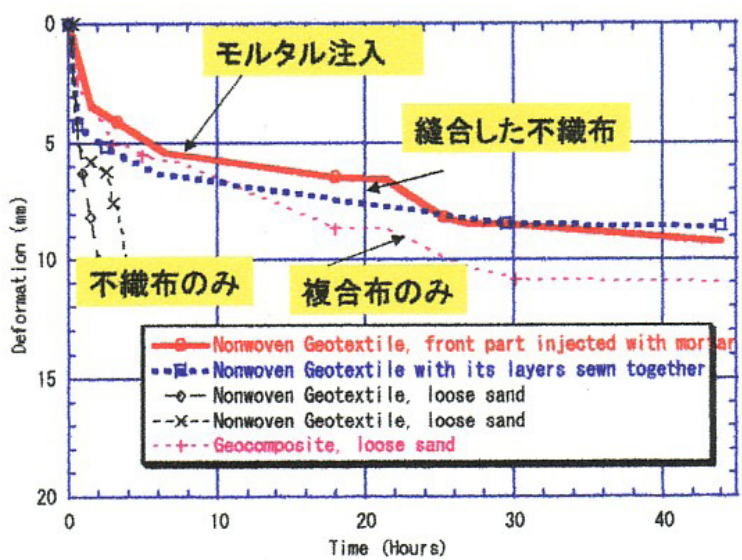

図-16 波浪作用による補強土壁の鈆直変位に及ぼすモルタル 注入の影響
も時間とともに沈下は収束する傾向にあるが，不織布の 場合は，縫合しなければ，盛土は引き波作用時に大きな 変位が生じ，早い時間に崩壊してしまう。したがって， 縫合の効果は，不織布の補強において有効であることが わかる，次に，モルタルを注入した結果を図-15 と同様 に整理した図-16 の結果を見ると，不織布では，複合不 織布のみの場合，および，縫合した場合とほとんど同様 の効果が見られる。したがって，これらの実験から，コ ンクリート護岸の代わりにジオシンセティックス補強護 岸を適用する場合は，以下の工夫が有効であることがわ かる.

i）ジオシンセティックスの種類 : 不織布よりは複合不 織布を適用寸るほうが護岸の変状対策には有効である.

これは, 複合不織布の大きな引っ張り張力と引張り剛性 に起因しているものと判断される.

ii）組み合わせ効果 : 不織布の場合は，縫合して材料の 張力・摩擦力を十分発揮させるか, モルタルを注入して 砂の強度を増加させることにより全体系の安定性が増加 する.

iii）基礎敷設の効果:図-17a, b に基礎を有しない場合と 有する場合の護岸盛土の結果をまとめている，縫合した ものについては，基礎のない場合の結果も示している. これによると基礎がある場合も，ない場合も縫合とモル
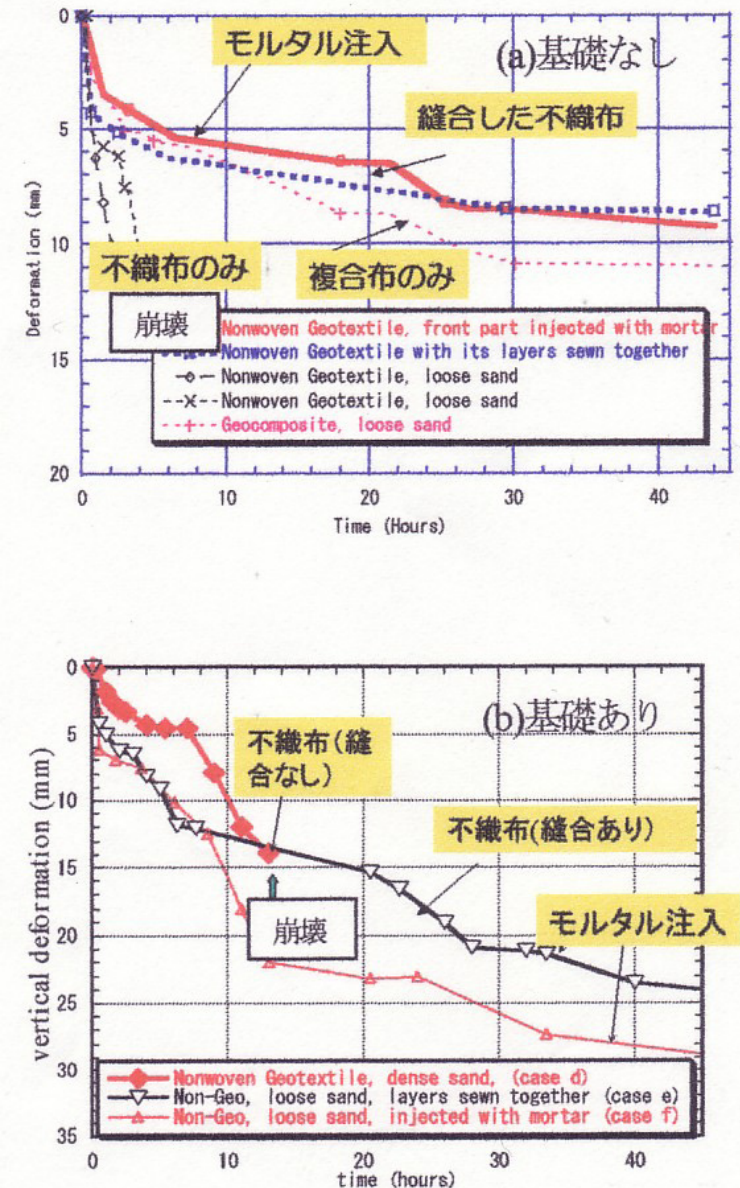

図-17 波浪の作用による補強土壁の鉛直変位に及ぼす基礎の 有無の影響 
表-2 強化復旧のための護岸補強土工法の利点と欠点の比較 ${ }^{10)}$

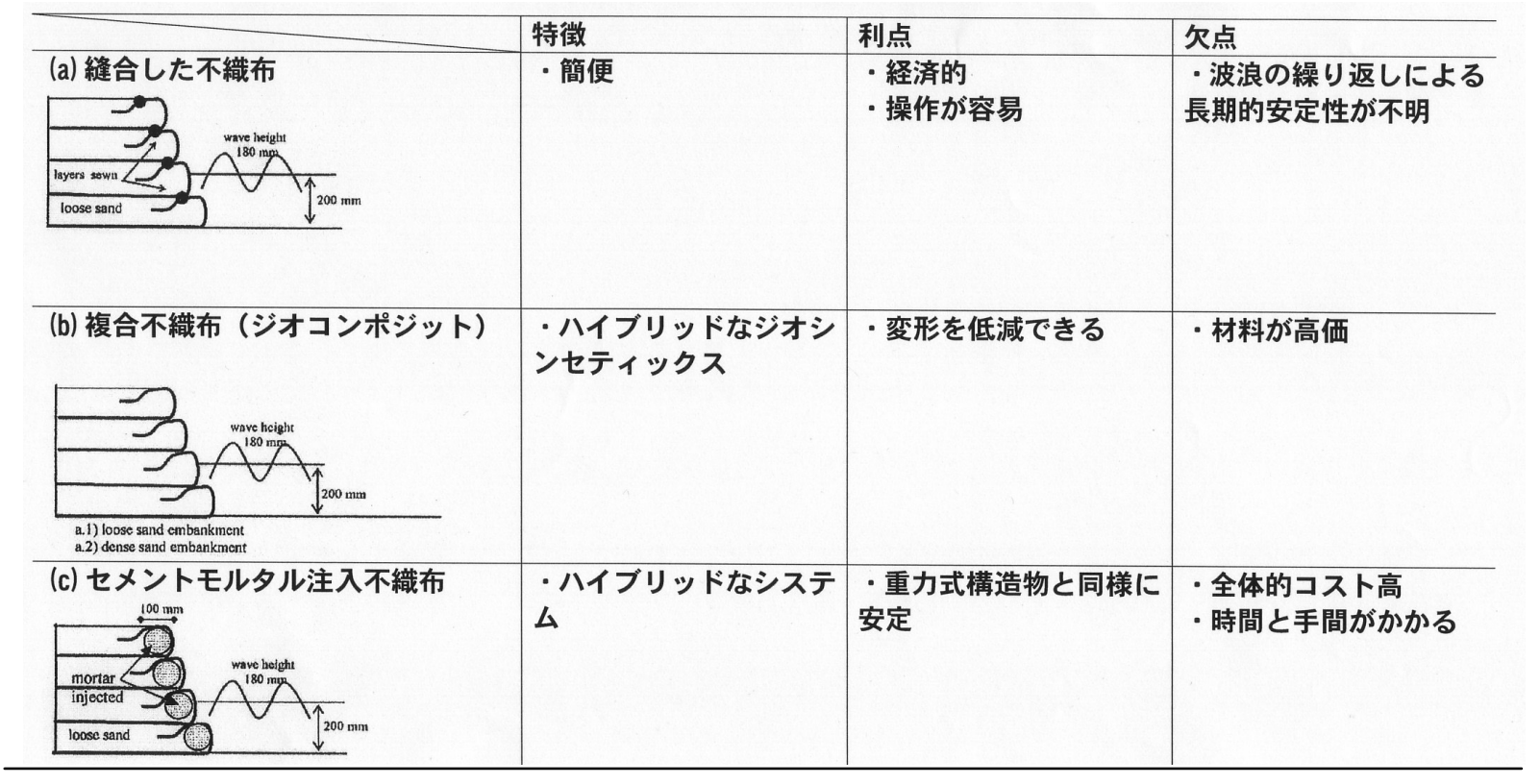

タル注入による補強の効果は同様に有効である.ただ, 縫合した場合は，基礎の変形にも追随してその結果基礎 も守られる. しかし，基礎の変形が大きくなるとき，こ れを制御する手段を講じるなどの配慮が必要であろう。

以上の結果から，表-2 にまとめたように，ジオシン セティックスによって海岸を防護するための有力な方法 として考えられる 3 つの方法，(a）縫合した不織布を適 用する方法，（b）ジオコンポジットを適用する方法 （縫合なし），（c）不織布で補強された護岸にモルタ ルを注入して安定化させる方法, を比較してみると, 経 済性と力学的安定性の面から総合して，（a）の縫合した 不織布を適用する方法がコンクリート壁を有しない護岸 構造物として推奨できると結論される.

\section{5. まとめ}

ここでは，東日本大震災時に地震動とともに地盤沈 降を受けた沿岸域における浸水の危険性を低減するため に，本復旧や強化復旧のための護岸構造物の築造に際し てジオシンセティックスを利用して，コンクリートなど の岡潂構造物に代わる, 変形追随型の柔な補強土護岸構 造物の構築方法を提案した. なお、ここで用いられる土 のうは，これまでに慣用されている土のうが応急復旧を 目的にしたものに対して，これをさらにグレードを上げ て本復旧や強化復旧に用いることを目的としたものであ る. 本研究で得られた結論を要約すると以下のとおりで ある.

1）土のうをジオシンセティックスによって補強して海 岸を防護するための有力な方法として考えられる 3 つの 方法，（a）縫合した不織布を適用する方法，（b） ジオ コンポジットを適用する方法（縫合なし），（c）不織 布で補強された護岸にモルタルを注入して安定化させる 方法，を取り上げ，これらの効果を二次元波浪水槽を用 いた模型実験によって比較した。その結果，(a) の縫合 した不織布を適用する補強土工法が経済性と力学的安定 性の面から有利であることから，コンクリート護岸に代 わる短期的な護岸構造物築造方法として推奨できる.

3)護岸に用いる土のうにセメントモルタルを注入するこ とによって，より強固な補強土護岸を構築できる.

以上のことから，波浪を受ける海岸対策工や高潮や 台風時の海岸防護壁体構造物として用いられるジオシン セティックスとしては，透水性があり，張力と剛性の高 い材料が適していると考えられる.

謝辞 : 本研究を進めるにあたつては，多くの方々のご協 力とご支援を戴いた．まず，石巻市震災復興部，宮城県 東部土木事務所の各位には現地をご案内戴いたり，資料 の提供を戴いた．東北大学風間基樹教授と東北学院大学 飛田善雄教授には行動を共にして戴くとともに，議論に 参加いただいた。また，パシフィックコンサルタンツ( 株) 東北支社の東瀬康孝氏には貴重なデータの提供を受 けた．付記して深甚の謝意を表する次第である．また， 本研究を進めるにあたっては，環境省総合研究推進費S8「温暖化影響評価・適応政策に関する総合的研究」( 研究代表者 : 茨城大学教授・三村信男）における, サブ 課題S-8-3「アジア太平洋地域における脆弱性及び適応 効果評価指標に関する研究(FY2010 - FY2014)」サブ課題 代表者 ・安原一哉）及び文部科学省科学研究費基盤研 究A「気候変動に起因するべトナム沿岸災害適応策のた めの統合型モニタリングシステム」（研究代表者・安原 一哉）の援助を受けた. 併せて深甚の謝意を表する次第 
クス技術情報，Vol. 18,No. 1,pp. 1-5,2002.3.

\section{参考文献}

1)朝日新聞 20115.20 朝刊

2) 薄井他 : 東北地方太平洋沖地震における地盤変動に関する準 備的考察, 第47回地盤工学研究発表会講演概要集，八戸， 2012.

3) 読売新聞 2011.3.20 朝刊

4) 宮城県 : 内部資料, 2011.

5) (財)土木技術センター編：「而㬋性大型土のう積層工法」設 計・施工マニュアル，平成24年3月.

6) 地盤工学会編 : 地震時における地盤災害の課題と対策 2011 年東日本大震災の教訓と提言，2012.4.

7) 安原 : 地盤構造物の高規格化へ向けたジオシンセティックス の新しい展開一過去の点描を踏まえて一, ジオシンセティッ
8) 安原・Recio-Molina, J. A.・村上・小峯: 波浪荷重を受けるジオ シンセティックス補強土護岸の設計法, ジオシンセティック 論文集，第 17巻, pp.201-206,2002.12.

9) Yasuhara, K., Ghosh, C. and Juan-Molina, J. A. : Advantageous features of the geo-composite learned from small-scaled model tests, Proc. $7^{\text {th }}$ Inten'l Cong. Geosynthetics, Vol. 1, pp. 435 - 440, IGS, Nice, France, 2002.

10) 安原一哉・村上 哲 Recio-Molina, J. A. : 沿岸域における護岸 のためのジオシンセティックスの適用, 国際ジオシンセテ イックス学会日本支部技術情報, Vol., 20,No. 3,2004.8.

11) Yasuhara, K. and Juan, R. : Geosynthetic-wrap around revetments for shore protection, Geotextiles and Geomenbranes, Vol. 10, No. 1, 1-12, 2007.4 .

12) 安原: 巨大地震に耐えた地盤と土構造物, ジオシンセティ ックス技術情報, 2011.7, pp.7-15.

\section{Potential Application of Geosynthetics for Reconstruction Following Coastal Land Subsidence Induced by the Great East Japan Earthquake}

\section{Kazuya YASUHARA and Takayoshi USUI}

We explored the potential of employing geosynthetics for the restoration of the coastal area in Tohoku where tectonic movement during the 2011.3.11 Great East Japan Earthquake caused large land subsidence. Based on the preliminary investigation, we have found that:

i) The flexible structures reinforced with geosynthetics are available not only for urgent remediation but also as permanent countermeasures against inundation increased by climate change-induced storm surges.

ii) The long-term monitoring of ground surface movement and sea-level rise is essential for determining what kinds of adaptive measure is most suitable at the objective site and when they should be taken in order to avoid inundation.

KEYWORDS: East Japan Great Earthquake, Land subsidence, Coast, Sea-level rise, Remediation, Geosynthetics 